\title{
H.L.A. Hart's secondary rules: what do 'officials' really think?
}

\author{
David Howarth" and Shona Wilson Stark
}

\begin{abstract}
The impact of H.L.A. Hart's The Concept of Law on modern legal thinking is undisputed. But does it reflect the reality of the way British institutions work? In Concept, Hart argued, amongst other things, that one of two 'minimum conditions necessary and sufficient for the existence of a legal system' was that 'its rules of recognition specifying the criteria of legal validity and its rules of change and adjudication must be effectively accepted as common public standards of official behaviour by its officials'. In this paper, we begin the process of testing that statement empirically. Specifically, we ask whether nonjudicial UK officials have a uniform view of what the rules of recognition, change and adjudication are, and whether they uniformly take an internal point of view towards them (i.e. whether they accept the rules and do not merely obey them). By way of a pilot study, thirty non-judicial UK officials were interviewed. Those officials comprised currently serving and retired senior civil servants, senior military officials, chief constables and local authority chief executives. The findings of the pilot study are presented in this paper. They allow us to deduce that Hart's statement might well be an inaccurate and incomplete description of the modern British constitution, and to comment on the implications of that conclusion.
\end{abstract}

\section{Introduction}

H.L.A. Hart's The Concept of Law plays a central role in modern legal thought (e.g. Endicott, 2013). The literature on it is now enormous. ${ }^{\mathrm{I}}$ It forms part of the mental apparatus of lawyers educated not only in the UK, but also throughout the English-speaking world and beyond. ${ }^{2}$ In it, Hart attempts, as he himself remarked later, 'to say something about law in general, [something that] has ... some claim to universality and ... not to be evaluative or justificatory, but descriptive' (Hart and Sugarman, 2005,

* Professor of Law and Public Policy, University of Cambridge, Fellow of Clare College, Cambridge. Clare College, Trinity Lane, Cambridge, CB2 ITL, UK. E-mail: drh2o@cam.ac.uk.

** Corresponding author. College Lecturer and Fellow in Law, Christ's College, Cambridge. Christ's College, St Andrew's Street, Cambridge, CB2 3BU, UK. E-mail: sw590@cam.ac.uk. The authors acknowledge the generous support of the LeRoux Trust. We also thank many people, especially Dan Priel, the participants in seminars in London and in Bergen (supported respectively by the Constitution Society and the Faculty of Law of the University of Bergen) and the anonymous reviewers, for their very helpful comments on previous drafts.

I Nearly I 2,00o citations are linked in Google Scholar - around the same as Richard Posner's Economic Analysis of Law. Of the 'major' jurisprudential texts, only Dworkin's Taking Rights Seriously with around I3,000 citations seems more cited (checked I2 October 2015).

2 Hart's work featured, for example, in $R$ (Miller and Dos Santos) v. Secretary of State for Exiting the European Union [2017] UKSC 5, the UK's single most significant constitutional case for many years, at [60], [173] and [223][227]. See also e.g. R (Jackson) v. Attorney-General [2005] UKHL 56, at [126]; Pham v. Secretary of State for the Home Department [2015] UKSC I9, at [80]; Kable v. Director of Public Prosecutions of New South Wales (1996) I89 CLR 5I, 74; Members of the Yorta Yorta Aboriginal Community v. State of Victoria [2002] CLR 422, 443, 446; $R$ v. Buzzacott (2004) I49 A Crim R 320 (Supreme Court of the ACT); and Motard c. Canada (Procureure Générale) 2016 QCCS 588. Hart's influence on courts and practitioners in the US is perhaps not as extensive, and his influence is mainly as an academic counterpoint to Dworkin and to Lon Fuller (Schauer, 2006) but see Sourbeer v. Robinson 79I F.2d. 1094 (US Court of Appeals, Third Circuit, 1986). 
p. 287). That 'something' most notably included an account of law that separated it from morality. But it also included an account of law's relationship with politics. It is that relationship that this paper takes up and challenges.

Hart argued in Concept that one of two 'minimum conditions necessary and sufficient for the existence of a legal system' was that 'its rules of recognition specifying the criteria of legal validity and its rules of change and adjudication must be effectively accepted as common public standards of official behaviour by its officials' (Hart, 20I2, p. II6). ${ }^{3}$ The rules of recognition of a legal system establish which rules count as part of the system and which do not. The rules of change lay down how the rules in the system can be altered. The rules of adjudication lay down which people or institutions settle issues of how the rules in the system apply in specific instances. Those rules, Hart's 'secondary rules', form a crucial part of Hart's theory that the way to understand law is as the union of primary and secondary rules. But, in addition, Hart's account includes a claim that the continuing existence of the legal system results from state officials holding a common view of those secondary rules and holding that view in a particular way: the 'internal point of view'. Hart's argument is that, unless state officials hold a common view of the secondary rules and hold it from an internal point of view, the system will send out contradictory instructions to the population and thus will be in danger of losing both legitimacy and effectiveness (Hart, 20I2, p. II6; see also Goldsworthy, 200I, pp. 240-242). The system will, in Kramer's vocabulary, lose 'operativeness' (Kramer, 2013, p. 45). ${ }^{4}$

Hart's account is undoubtedly interesting and fruitful. One obvious question about it, however, seems not previously to have been asked. Is it true? Do officials in fact hold a common view of the secondary rules from an internal point of view? This paper reports on the results of a study, admittedly a small-scale and exploratory pilot study, that suggests that the answer might eventually turn out to be 'no'.

\section{Hart's claim - a uniform internal point of view}

Hart's claim, to be more specific, is that it is 'crucial ... that there should be a unified or shared official acceptance of the rule of recognition' (Hart, 20I2, p. I I5). That idea breaks down into two elements: that officials should have a shared view of the secondary rules and that they should 'accept' those rules. The first element is reasonably clear. 'As a guide', Hart says, officials' view of the secondary rules has to be 'uniform' (Hart, 20I2, p. 258; and see also pp. 266-267: 'the rule of recognition is treated in my book as resting on a conventional form of judicial consensus'). For a legal system to persist, the rules of recognition, adjudication and change accepted by officials have to be the same rules, uniformly interpreted. That is because otherwise the system will generate contradictory instructions to the population at large.

The second element - acceptance - is less clear. Hart distinguished between the external and internal aspects of following a rule. The external aspect of rules concerns what can be observed by others: the extent to which behaviour appears to conform to the rule. The internal aspect relates to a person's attitude towards the rules, in particular whether they understand and accept them (Hart, 20I2, p. 60). Hart claims that a difference exists between ordinary citizens and officials in what is required of them. External following of the rules is required of both, but taking the internal point of view is required only of officials (Hart, 20I2, pp. II6-II7). This is not simply a

3 The other necessary minimum condition was that 'those rules of behaviour which are valid according to the system's ultimate criteria of validity must be generally obeyed': Hart (20I2, p. I I6).

4 The issue of whether lack of 'operativeness' means that a legal system no longer 'exists' is a separate question. Certain writers assert that even a legal system that the population at large completely ignores can still 'exist': see Tamanaha (200I, pp. I45-I47). Such a situation is possibly better described as a factitious legal system. 
matter of having to be an expert to understand the rules (Hart, 20I 2, p. 60). Understanding the rules is not enough. Hart is concerned with something else:

"[P]rivate citizens ... may obey each "for his part only" and from any motive whatever ... [Officials] must regard these as common standards of official behaviour and appraise critically their own and each other's deviations as lapses.' (Hart, 20I2, pp. II6-II7)

The most straightforward explanation for this requirement is that officials correcting one another in cases of non-compliance helps to maintain uniformity. The point of view is 'internal' in the sense that it is used in the internal social interaction among officials. ${ }^{5}$ No similar need exists for the general public to accept the secondary rules, presumably because Hart thinks that no confusion about which rules are authoritative can arise from variation in the views of non-officials. ${ }^{6}$ In an extreme case, Hart says, the internal point of view might be confined exclusively to officials - producing a society, he comments, that might be 'deplorably sheeplike' (Hart, 20I2, p. II7) and 'the sheep might end in the slaughter-house', but one which would still have 'a legal system'.

It makes no difference, however, why officials use the rules as standards to criticise other officials. Officials need not accept the secondary rules through feeling 'morally bound to do so', although, Hart goes on to say, 'the system will be most stable when they do so' (Hart, 20I2, p. 203). He continued:

'[T]heir allegiance to the system may be based on many different considerations: calculations of long-term interest; disinterested interest in others; an unreflecting inherited or traditional attitude; or the mere wish to do as others do. There is indeed no reason why those who accept the authority of the system should not examine their conscience and decide that, morally, they ought not to accept it, yet for a variety of reasons continue to do so.' (Hart, 20I 2, p. 203)

The internal point of view is not 'internal' in the sense of being related to one's deepest convictions or in the sense of 'authentic'. An official who disapproves of the constitution maintains the internal point of view by refraining from making that disapproval public. Successful simulation of approval is just as much taking the internal point of view as enthusiastic endorsement.7

\section{Preliminary objections}

Two sorts of objection might immediately be made to a project of investigating whether Hart's claim is true. First, is Hart's claim really empirical? Although Hart famously characterised Concept as an exercise in 'descriptive sociology' (Hart, 20I2, p. vi), he later regretted it (Lacey, 2006, p. 949). Instead, one can read it as a purely philosophical work, arguing for a view of what law must be, not of what it happens to be. Nevertheless, as John Gardner points out, Hart, in his unfinished Postscript to the book, continued to insist that his work was 'descriptive' (Gardner, 20I2, p. 275, discussing Hart, 1994). In particular, Hart says he is providing a description of others' practices and, although that description involves interpretation of those practices in a 'hermeneutic' sense

5 Hart's position on this issue in his Postscript is essentially the same. He continued to refer to acceptance (and not mere obedience) by officials and to insist that such acceptance is essential for the 'existence and authority of the rule of recognition': Hart (2012, p. 250).

6 This is not expressly stated, but seems to follow from Hart (20I2, p. II6).

7 These passages have resulted in some puzzlement, especially since subsequently Hart adopted Raz's view that it is possible to put forward propositions of law in a 'committed' or a 'detached' way (or in Kramer's vocabulary, to distinguish between the 'internal' and the 'simulative'). But the essential point is whether the official is contributing to or detracting from the maintenance of uniformity. 
(Hart, I983, pp. I3-I4), ${ }^{8}$ it does not draw him into evaluating them (Hart, 20I 2, pp. 239-244). That remains the case, says Hart, even though the practices themselves might be evaluative.

Gardner raises a different version of this objection. He says Hart's theory, regardless of what Hart intended, cannot be empirical. Gardner claims that one has to know what law is before one can make empirical statements about it. Hart's theory is about what law is. It tells us what to look for if we want to make empirical statements about law. Thus it must be prior to those empirical statements (Gardner, 20I2). The problem with Gardner's objection is that it makes a claim very difficult to justify about the relationship between philosophy and empirical sociology. A social phenomenon does not need to make philosophical sense for it to be a possible object of empirical study. If, for example, people use the word 'law' in many different and incompatible ways, that is an empirical fact we can report without needing the permission of philosophers to use the word 'law'. No doubt sociologists can benefit from philosophical reflection about their methods, and the concepts at the heart of their methods do have to be coherent. But that is very different from claiming that the objects of empirical study must make sense.

A more refined and powerful version of Gardner's point, however, is that Hart was engaged neither in a purely philosophical forging of concepts nor in empirical study, but in a third activity that of constructing out of existing social practices concepts for use in future empirical study. Hart remarked: 'What I should have said is that it provides the tools for descriptive sociology, not that it is descriptive sociology' (Hart and Sugarman, 2005, p. 29I). Denis Galligan has pointed out the striking similarity between Hart's method of drawing upon existing social practices, specifically those around creating and following rules, to develop his 'concept' of law and Max Weber's method of ideal types (Galligan, 20I5). Weber's ideal types are analytically useful constructs built out of one-sided accentuations of existing social practices to help the observer understand social action (Weber, I949, p. 90). The parallel is not exact, since Weber's ideal types are not required to be philosophically coherent, only 'adequate at the level of meaning' - that is, make sense at the level of the individual whose actions they help the observer to understand. Consequently, ideal types can encompass inconsistent and 'irrational' action, not just 'rational' action (Weber, I978, pp. 19-22). Hart, in contrast, strenuously tries to make his concepts coherent. Also, whereas Weber, having constructed a set of ideal types, would then compare them with the empirical world, the better to understand that world through a process of assessing where the ideal types work and where they fail to work, Hart only carries out the first phase. He constructs an ideal type or 'concept' but does not go on to apply it.

If this account of Hart is correct, and it is certainly more than plausible, the project proposed in this paper should be taken as a contribution to supplying Hart's concept with its missing second phase. It applies Hart's concept, his ideal type of officials, to some of the empirical facts to see to what extent it explains those facts. ${ }^{9}$ If the concept does not explain all of the empirical facts, the concept and not the facts will stand in need of revision.

8 Rejecting what Hart calls the 'empirical' approach of the Scandinavian realists. In sociology as practised by, for example, Max Weber, however, no contradiction exists between being interpretive and being empirical. Indeed, even in the supposedly non-interpretive sociology of the Durkheimian tradition, in sharp contrast with the rather crude materialism of the Scandinavian realists, what makes empirical sociology possible is the existence of specifically social facts.

9 One should note that, although ideal types cannot be refuted by empirical evidence, they can be shown to be 'inadequate', either because they explain too little to be worth bothering with or because they make no sense at the level of the individual. That distinguishes the ideal-type approach from another argument that undermines not only any empirical investigation of Hart's claim, but also the claim itself. This is the possibility that Hart's claim is unfalsifiable because, whatever evidence of lack of uniformity or of the internal point of view one might discover, proponents of Hart's view might say that, because the legal system is still functioning in some way, the degree of lack of uniformity and of the internal point of view 
The second objection to our project is that, although certain well-known examples exist of UK judges musing about whether they will always accept the doctrine of parliamentary supremacy, ${ }^{\text {Io }}$ no evidence appears in their judgments that they accept anything else, ${ }^{\mathrm{II}}$ still less that they disagree about the power of parliament to change the law or their own right to adjudicate on what the law is. One might be able to tease out subtle differences about, for example, how the law might change through common-law adjudication or the extent to which courts' deference to other decision-makers involves an abrogation of their own powers to adjudicate, but ultimately these are minor differences of little practical importance. The objection is therefore that too little variation exists for any such empirical study to be interesting.

But, even if that is so, what judges believe does not exhaust what 'officials' believe. What about civil servants, military officers, police officers or local government officials? What do these officials believe to be the rules of recognition, adjudication and change? Do they treat them as common public standards? It is potentially just as destructive to stability to receive contradictory instructions from civil servants, military officers, police officers or local government officers as from judges. These are, as far as we know, questions never before asked and ones where variation in the answers is entirely possible given that other researchers have found that our executive consists not of a 'compact monolith, but a loosely structured conglomerate' (Daintith and Page, I999, p. 8; see also Bevir and Rhodes, 20I0, p. I98). This study therefore starts to investigate the views of non-judicial officials - senior civil servants, senior military officers, chief constables and local government chief executives - about Hart's secondary rules. ${ }^{12}$ In 1999, Daintith and Page made great strides in addressing the 'long-term neglect' of the executive as a subject of academic study (Daintith and Page, I999, p. I). As they correctly observed, it is 'bizarre' to overlook the constitutional importance of the executive branch (Daintith and Page, I999, p. 2; an in-depth study of the executive in the context of making delegated legislation was carried out in Page, 200I). This study seeks to add to the correction of that omission.

An objection to studying non-judicial officials might be that their views are not important for the existence of a legal system or for understanding constitutional law. Our view, however, is that, in constitutional law, as in many areas of law, the courts play a very limited role. In private law, contracts are drafted, concluded and carried out all the time without judges getting anywhere near them; companies are formed and operated on the basis of their founding documents without any help from the High Court. Similarly, in public law, regulations on myriads of topics are applied, both by government agencies and by private parties (the latter often applying the law to themselves) without any court pronouncing on how they should be interpreted. If one wants to know how the law operates in these fields, one has to look at how it is applied every day in reality. Indeed, the appearance of a court decision involving UK constitutional law is an event rare

cannot have been enough to affect the 'operativeness' of the system. This reduces Hart's claim from a causal claim to a meaningless play on words.

Io For example, $R$ (on the application of Jackson) v. Attorney General [2005] UKHL 56; AXA General Insurance Limited and others $v$. The Lord Advocate and others [20I I] UKSC 46.

I I See e.g. $R$ (HS2 Action Alliance Ltd) v. Secretary of State for Transport [20I4] UKSC 3, where Lord Reed, with whom the other six Justices agreed, was 'mindful of the importance of refraining from trespassing upon the province of Parliament or, so far as possible, even appearing to do so' (at [95]).

I 2 One might also ask what views ministers themselves might have about these topics. We have, however, excluded ministers at this stage. We do not intend by this to imply that ministers are not crucial players in the executive branch of government. They plainly are. It is simply that a finding that politicians disagreed about Hart's secondary rules or failed to take the internal point of view towards them would be too easy to dismiss as unsurprising and unimportant: unsurprising because constitutional issues are part of politics and unimportant because, outside parliament, ministers have little capacity to act except through their officials. Confining ourselves to officials is to take on a harder case to prove than if we had included ministers and thus, we hope, potentially more persuasive in its results. 
enough to be commented upon for its very existence, and yet the constitutional system operates every working day. As Yong has noted, if we only study the courts and parliament, we cannot see 'how the Executive regulates itself internally' (Yong, 2013, para. I.4). If one wants to know how the constitution works, one needs to know the views of the officials who operate it.

The seniority of the officials is, nevertheless, important (see Goldsworthy, 200I, p. 238, n. 4). They are in a position to affect the 'operativeness' of the system from the top down. Cabinet secretaries, permanent secretaries, chiefs of the defence staff and senior generals control considerable resources and, more importantly for our purposes, act as gatekeepers between political leaders and effective power - that is, between political decisions being taken and citizens being given instructions about what to do or how to do things. The scope of investigation should also extend to the views of chief constables and local authority chief executives - officials who, although limited in terms of geographical jurisdiction, are subject to no administrative superiors and who also act as gatekeepers between politics and effective power.

Admittedly, it is possible that 'street-level bureaucrats' - those charged with the exercise of discretion in individual cases - might be able to restore the operativeness of the system at the bottom, by incorporating into their decisions values and judgments from beyond the law or by selective inattention to it, constructing coherence out of incoherence (Lipsky, I980; MaynardMoody and Portillo, 20Io, pp. 253-277, especially at pp. 269-270; Mashaw, I983; Howarth, I992, pp. 29-53, deriving from Garfinkel, I967, pp. 76-103). But a situation in which senior officials differ about fundamental questions of authority would pose a much bigger challenge for lowerlevel officials than the usual problem they face of individual policies being unclear or incomplete. Each gap in a policy or each unclear statutory provision affects only a subset, usually a small subset of lower-level officials, so that one can see how a common street-level view might emerge (even though divergence is also a distinct possibility). Constitutional incoherence, however, would be more difficult to confine to small subsets of officials. For lower-level officials to be able to restore constitutional coherence, one would have to imagine a situation in which they all shared a single understanding of the constitution and that shared single understanding was unaffected by the views of senior officials. That is possible, but, we believe, unlikely. ${ }^{\mathrm{I3}}$

Objectors might come back with the argument that even these very senior appliers of the law are themselves subject to the courts and so their views are ultimately subordinate to those of judges. That argument, however, assumes too much. Although other actors might be aware of the possibility of judicial intervention, it is an empirical matter whether that possibility makes any difference to how they act. Even in terms of public perception and ultimate loyalties, it is not obvious a priori whether, were a conflict to break out between the courts and non-judicial officials about the most basic rules of the constitution, the public would side with the judges. ${ }^{\mathrm{I}}$

I3 A further possibility, perhaps for future development, is that the separation of government into separate silos operates to contain and mitigate the effects of incoherence at the centre. As long as incoherence derived from other silos can be ignored and citizens fail to notice the interactions between the silos, the system can still at least appear to function. This perhaps explains both calls for 'joined-up government' (because of instances when citizens do notice cross-silo incoherence) and why it is so difficult to achieve.

I4 Another preliminary objection is to ask how, without knowing the law, can we say that a particular person is an official? Just as Gardner argues that one has to know what counts as law before making empirical statements about law, is it not also the case that we cannot tell which persons are officials without knowing the law that makes them officials? Hart himself has been accused of 'circularity' on this point officials only exist because of the rule of recognition, but the rule of recognition only exists because the officials conform to it (see Leslie Green's notes in Hart (20I2, p. 316); MacCormick (2008, pp. 34, I36-I37)). The problem is not just an epistemic one of the kind 'how do we know whether someone is an official?', but also an ontological one of the kind 'who counts as an official?'. One could spend a very great amount of time on such questions (see e.g. Searle (I995, Chapter 2)). The question for the present study, however, is merely whether the fact that Hart himself proposed no solution to the circularity problem poses a threat to the project of testing Hart's theory empirically. We would maintain that it does not. It 
A mirror-image objection might be to claim the law does not much matter for the operativeness of government. Where government operates through contracting out, for example, the legal enforceability of the relevant contracts might matter less for whether they are carried out than long-term reciprocal relationships between the parties. Where government operates through coordinating its activities with those of other organisations, that is where 'governance' operates through 'policy networks' (Rhodes, I997; 2007), its relationships with those other organisations might have no legal force at all. But Hart is not interested in government (or 'governance') in general. He is interested in the legal system. Admittedly, if the legal system were completely ineffective, questions about how it worked would be of no interest, but it would be surprising if theorists who point to other ways in which government operates were making such an extreme claim. ${ }^{15}$

One final objection is that, no matter how inherently interesting the views of non-judicial officials are, studying them will give us no purchase on Hart's views because, when Hart referred to 'officials', he meant only 'judges'. This interpretation is, however, inconsistent with the text of Concept. Hart himself referred numerous times to 'courts or other officials' (Hart, 20I2, p. IOI, emphasis added). ${ }^{16}$ In fact, Hart's own usage seems deliberately wider than ordinary usage, not narrower. At one stage, for example, Hart says 'laws ... give powers to officials, e.g. to a judge to try cases, to a minister to make rules, or a county council to make by-laws' (Hart, 20I 2, p. 26). ${ }^{17}$ Given Hart's own text and the breadth of his own usage, we can be reasonably sure that, when he said that it is a necessary and sufficient condition for the existence of a legal system that 'officials' accept rules of recognition, change and adjudication, he was not exempting non-judicial officials (see also Goldsworthy, 200I, pp. 240-24I). Of course, other writers, in particular Joseph Raz, have sought to restrict the relevant set of 'officials' to judges, but Hart himself, we believe, did not. ${ }^{8}$

might be a threat if the people we identified as officials turned out not to be officials according to law, since then we would have been studying the wrong people. Nothing, however, indicates that those we studied were anything but duly appointed to their offices.

I5 The ontological issue referred to above in note I4 also lurks behind this objection. If 'government' is a legal concept, there is an irreducible legal element in talk about 'government' acting through contract or policy networks. Political scientists tend to assert that Britain has never adopted the theory of the Rechtsstaat, denying the very existence of a state outside the law, but, as the ambiguity of Hart's own theory illustrates, it might be better for our purposes to treat the issue as unresolved.

I6 See also e.g. p. 2: 'official or ... court'; p. Io: 'judge or official'; and p. 67: 'courts, officials'.

I7 Note that the reference in this passage to County Councils justifies including local government officers within the category of officials. For the inclusion of the police, see Hart (20I2, pp. 20, 39). It is also worth mentioning that to call a judge 'an official' is itself mildly controversial - judges might see themselves as 'officers' of the state but, in British English, in which the usual meaning of the word 'official' is 'civil servant', calling them 'officials' makes them sound as if they are subordinate to politicians. Counting ministers as 'officials' is also not ordinary British English. The category of 'elected official' is American. In Britain, the categories 'official' and 'politician' are usually thought mutually exclusive. In his introduction to the third edition of Concept, Green even says that Hart intended to include legislators within his definition of 'officials', which would go even further beyond ordinary British usage (Hart (20I2, p. xxix)).

I8 Raz distinguished between 'norm-creating' and 'norm-applying' institutions and among the latter between 'primary' institutions, such as courts and other institutions, such as the police, with only the 'primary' institutions claiming an essential role in a legal system (Raz (I979, pp. I05-I IO)). At one point, Raz claims that it is not only in his own view but also 'presumably' Hart's view that 'official' means only a 'primary norm-applying’ official (Raz (I979, p. 92)) (see also Green’s Notes to Hart (2012, p. 3I7)). But Hart himself refers not to law 'applying' officials, but to law 'identifying' officials, which he does not restrict to courts (see 'Kelsen's Doctrine of the Unity of Law' in Hart (1983, pp. 335-337)). Raz's view itself, one might mention in passing, seems to leave civil servants as non-primary law-applying officials, alongside the police. That seems a very thin view of the role of senior civil servants in a modern state. The law they apply in their everyday work is not enforcement of existing rules, but is rather law that refers to themselves and usually concerns their own powers. The modern 'executive' does rather more than 'execute' the law. Raz's view might work for identifying the minimal conditions for identifying a 'legal 


\section{A pilot study}

With these preliminaries out of the way, we can now turn to how we might investigate Hart's claim empirically. The hypothesis we want ultimately to test is that UK non-judicial officials adhere to a uniform internal point of view towards the UK's rules of recognition, adjudication and change. That means (I) having a uniform view of what those rules are and (2) uniformly taking an internal point of view towards them.

Both questions involve issues of interpretation and nuance. It is not the case that only one way exists of stating the same rule. A difference in the precise formulation of a rule does not entail a difference about the content of the rule. Similarly, agreement about a verbal formulation does not in itself entail uniformity in how it is applied. In addition, the hypothesis we want to test is not that officials agree with a specific formulation of the rules of recognition, adjudication and change, but that they hold the same view of those rules as one another, whatever view that is. As a result, a method that imposed or presupposed 'correct' views of the rules would be inappropriate. Officials need to be able to speak for themselves.

All this suggests that the appropriate method for approaching the question is qualitative and interactive. For our pilot study, we chose to carry out semi-structured interviews, using a standard series of prompts but allowing conversations to develop around them. ${ }^{\mathrm{I9}}$ The prompts themselves consisted of putting to respondents two or three recent examples of UK constitutional rules coming under stress. ${ }^{20} \mathrm{We}$ chose to use specific real-life examples of problems of recognition, change and adjudication, rather than to address those issues abstractly, for two reasons: first, just as in the case method of legal education, at least when done well, discussion of specific cases is

system' for anthropological purposes, but one might question whether it meets Hart's objective of ensuring that citizens do not face contradictory rules.

I9 The standard caveats about semi-structured interviews should be given: variation in the order in which points were made or in the wording of questions is inevitable and might have had effects on responses; especially since building rapport with the interviewee is an important part of the process, interviewers can unconsciously give out cues about 'preferred' answers; because no controls are made for other factors, there is no certainty that a respondent would give the same response on another day; and coding is difficult because interviewees are always in effect answering different questions. In addition, in interpreting the results, researchers should remember that interviewees might not be telling the truth, might not understand their own motivations and might not act in accordance with their own beliefs about what they should do. Cf. Bevir and Rhodes (2010, pp. I56-I57): 'They can be candid statements, expressions of self-interest, or exercises in myth making. There are always the questions of how to interpret the data, and the extent to which their expressed views shaped their own practices and the practices of others.' One can sometimes cross-check what interviewees say using publicly available sources (autobiographies, for example) but those sources often suffer from similar problems and, in any case, officials of the kind we are here interested in very rarely write autobiographies or even give on-the-record interviews. For an exception, see Peter Hennessey's interviews of Cabinet Secretaries at <http://www. cabinetsecretaries.com/> (accessed 29 March 2017), quite appropriately headed 'Men of Secrets'. Little or nothing emerges in those interviews on the issues we are here studying. Another possible cross-check would be direct observation of officials at work. The problems of access for this kind of ethnography are, however, considerable and the resources required to do it across government would be substantial. We content ourselves at this point to asking whether our results are compatible with those of previous ethnographic studies, e.g. those of Page (200I) and Bevir and Rhodes (2010).

20 The specific prompts may be obtained directly from the authors. Our method differs from that of Page (200I), who sought to examine the workings of government by studying its more 'day-to-day' processes, claiming that big issues are 'atypical' (p. I6). We found that prompting our interviewees by referring to 'big issues' with which they were familiar led to them drawing analogies with smaller issues in their day-to-day work. Our method is derived ultimately from the case method developed by Karl Llewellyn for his study of the law of the Cheyenne: Llewellyn and Hoebel (I94I). We also take comfort for this approach from Bevir and Rhodes's observations that 'Top civil servants and ministers learn through the stories they hear and tell another' and that 'Most if not all civil servants will accept that the art of storytelling is an integral part of their work': Bevir and Rhodes (2006, p. I I8). 
less likely than abstract discussion to elicit merely formulaic 'acceptable' answers; and, second, as in behavioural interviewing of candidates for jobs, information elicited from examples in the interviewees' own experience and knowledge are likely to be a better guide to behaviour than purely hypothetical situations.

The main risk of this method is that the specificity of the examples might draw attention away from important ideas and practices not relevant in those situations but relevant in other cases. Asking interviewees for their own examples to some extent mitigated that risk, as did providing a variety of examples to each interviewee. We cannot, however, pretend that our method reveals the whole range of constitutional ideas and practices within government. What it can do, however, is to illustrate the existence of certain ideas and practices.

One other potential risk in this method should be mentioned. In accordance with normal ethical principles for this kind of research, all interviewees were guaranteed anonymity. The specificity of the examples, however, heightens the risk that reporting their remarks might tend to identify them. We have endeavoured to ensure that we have not reported views in any way that might identify individuals. To achieve that, however, we have had to edit quotations and to leave out altogether some highly relevant observations and examples.

\subsection{Sampling issues}

Turning to our sample, invitations were sent out to current permanent secretaries and to recently retired officials of the same rank whose whereabouts were publicly known (thus introducing a slight bias in favour of those whose careers in public life had continued post retirement, although we judged that there was no obvious connection between that fact and their views on the issues at hand). Local government chief executives from three English counties were invited, as were chief constables, together with a few further local government figures, from a slightly wider area. Some retired chief constables were also included from that wider area. While we accept that views on constitutional matters might have changed at least incrementally over time, ${ }^{2 \mathrm{I}}$ so that variance might occur purely on a generational basis with no consequences for the functioning of the system at present, so making that a factor to take into account when interpreting the results, we have no reason to believe that views on constitutional issues vary geographically.

The study was in the nature of a pilot study but we aimed to interview enough people to be able at least to make reasonable suggestions for future research. We interviewed thirty people - just under 50 per cent of those we approached. Our interviewees came from a variety of government departments, both foreign-policy-related and domestic. ${ }^{22}$

Access to senior civil servants is not easy to obtain, and might be a serious problem for any fullscale follow-up. Indeed, that difficulty is a principal reason for reporting the results of the pilot study and not waiting for a full-scale study. Our interest was in constitutional matters rather than matters of politics or policy, but some civil servants cited the Civil Service Management Code 2015, paragraph $4.2 .8,{ }^{23}$ which forbids participation in research into civil servants' political and policy opinions, as a reason for not being interviewed, with the result that we spoke to rather more retired officials than current ones. In addition, officials in one department, the Treasury, insisted that constitutional matters were nothing to do with them - a matter of interest in itself - and referred us to the

2 I Cf. Bevir and Rhodes's concept of a 'living traditions' that is 'adaptable sets of beliefs that enable those acting in the political sphere to understand and make sense of their world... sometimes resilient and enduring, and at other times ambivalent or contradictory in their core belief': Bevir and Rhodes (2010, p. I39).

We refrain from listing the individual departments so as not to jeopardise anonymity.

23 〈https://www.gov.uk/government/uploads/system/uploads/attachment_data/file/4I8696/CSMC-_April_20I5. pdf $>$ (accessed 29 March 2017). 
Ministry of Justice and the Cabinet Office. As a result, if variants on the rules exist in the Treasury, which is entirely possible, we are not in a position to report them.

One other possible source of bias was that one of us had previously worked in the vicinity of Whitehall and there was a tendency for the acceptance rate to be higher among those personally known to the researchers. Since the hypothesis we were testing was one of uniformity, we recognised that this particular bias might be a problem if uniformity did appear, but that, if uniformity did not emerge, this aspect of the sample would strengthen the result rather than weaken it.

\subsection{Sample size}

Since we are testing a hypothesis of uniformity, a single counter-example serves to refute it. That means that, if we find any difference between respondents, the hypothesis should be rejected. Sample size is therefore for this purpose not relevant, only the accuracy of the judgment that we have indeed found a counter-example. Statistical methods are not required and so, for this judgment, no issue of sampling error arises. Statistical methods and sampling error do become relevant, however, if the question is not whether uniformity exists, but instead by how much reality varies from uniformity. With only thirty respondents, confident inferences about that issue are unlikely. We would need a bigger sample in a full-scale study. We are therefore inevitably vulnerable to the argument that, even though we might discover lack of uniformity, its degree might turn out to be not enough to threaten the operativeness of the system. We consider this point further below, but we concede that, with this sample size and at this stage of the study, we are looking to establish merely whether lack of uniformity exists and whether further investigation is likely to be worthwhile rather than finally to establish whether operativeness is threatened.

Sample size also becomes relevant in the opposite direction: how many officials do we have to interview before we can justifiably conclude that uniformity exists? After all, even if we observe a very large number of officials saying the same thing, how do we know the next official we might have asked would not have disagreed? The answer to this classic problem of induction is, of course, that we cannot know for certain. All we can do is express our uncertainty in terms of probabilities. Whether these probabilities are sufficient is not something that admits of a single answer, but we can say something about how a rational person would update their views given the evidence (see e.g. Jackman, 2009, p. 7). If, for example, someone who thought that, on the basis of the information available to them, uniformity of views on constitutional issues by state officials was very unlikely - say a probability of 0.05 - and they observed a sequence of thirty state officials saying the same thing on a constitutional issue, something that would happen by chance once in a billion times, assuming a 50:50 chance of agreeing or disagreeing with the previous official, the observer would have to raise their probability that there is uniformity on the particular matter in hand to near certainty. ${ }^{24}$

24 This follows from Bayes's Theorem with $\mathrm{P}(\mathrm{H})=0.05, \mathrm{P}(\mathrm{E} \mid \mathrm{H})=0.99$ (that is the probability of the evidence if uniformity is true - allowing I per cent for errors in interpretation) and $\mathrm{P}(\mathrm{E} \mid \neg \mathrm{H})=0.00000000$ ( that is the probability of the evidence if uniformity is not true, here set at the binomial probability on the assumption that the only other way this could come about is by chance - of course, if there were an alternative hypothesis, this number could be higher and the posterior probability correspondingly lower). If the observer thinks that the probability of agreement with the previous official is higher than 50:50 (perhaps because of a view about the biases of those doing the coding or bias in the precise question being used), $\mathrm{P}(\mathrm{E} \mid \neg \mathrm{H})$ can be much higher. In the same example, if the probability of agreement is thought to be 0.9, the binomial probability is 0.04 , but the posterior probability of uniformity still rises to 0.57 . 
It is inherent in using semi-structured interviews that not all interviewees will have given useable answers on all the issues of interest. ${ }^{25}$ Where we claim that there is evidence of uniformity on the basis of fewer than thirty responses, we will say so.

\subsection{The internal point of view}

Testing the claim that officials take a uniformly internal point of view presents specific problems, especially if it is enough for officials successfully to give a false impression that they believe in the rules. The one crucial element of the internal point of view that might be observable, however, is whether officials comply with the law at all. If officials decide consciously to break the law, it is difficult to argue that they are displaying an internal point of view towards the system. ${ }^{26}$ Hart allows obeying the law for prudential reasons to count, because that will contribute to stability, but disobeying for prudential reasons has an entirely different effect on the 'operativeness' of the law. If we accept that taking the internal point of view is important because those who take it will correct other officials who appear to be straying from the common line, it is important that an official who openly disobeys or disregards the law is in no position to criticise others for acting in a similar manner. The credibility of such an official as a stabilising influence will be compromised. ${ }^{27}$ In contrast, an official who refuses to follow an unlawful instruction will invariably be involved in at least implicitly criticising those who gave the instruction and so will be displaying the internal point of view. ${ }^{28}$ We therefore asked our interviewees about what happens when a minister instructs an official to act outside the bounds of the law, both for what officials themselves would do and for what they collectively would think about a colleague who did not comply with such an instruction.

It might be objected that we should distinguish between disobedience of specific rules of law and refusals to accept the secondary rules themselves, with only the latter constituting a threat to the stability of the legal system. Certainly we should pay particular attention to direct refusals to accept the secondary rules themselves, but any disobedience of the law by a senior official at the

25 For example, if only the current and former senior civil servants we interviewed ( $n=\mathrm{I} 6)$ responded to an issue, the corresponding binomial figures are I. 5 in I00,000 and 0.I 85, so that applying Bayes's Theorem as above a very sceptical observer (prior $=0.05$ ) with a 0.9 question would, if confronted with sixteen positive responses, only reach a posterior probability of 0.22 , but, for a 50:50 question, the same very sceptical observer would reach near certainty. If the prior was 0.5 , that is the observer thought on the basis of prior experience that the probability of uniformity was a 50:50 chance, the posterior even with a 0.9 question would be 0.84 .

26 Cases of officials breaking the law have been reported in other jurisdictions, although not at the level studied here. For example, Davis described various instances of American police officers modifying or nullifying gambling or jaywalking laws: Davis (I97 I, pp. 84-96). This led him to remark provocatively that 'The law for Chicago is not what the legislature enacts; it is what the police chief says to the newspapers' (p. 85).

27 One argument put to us is that, since Hart is a legal positivist who separates law from morality, a decision to disobey must for him ultimately be solely a moral decision with no further significance. The difficulty is that Hart clearly does distinguish between the significance of what officials do and what non-officials do. Another argument is that Hart is concerned with the attitude of officials rather than their behaviour. That is true, but what we are saying is that one can infer attitudes from disobedience in a way one cannot from obedience. The reasons for obedience are many and varied and might not include an acceptance of authority, but the reasons for disobedience must include a defiance of authority.

28 An intermediate possibility is for the official to resign to avoid being personally implicated in the illegality. Where such a resignation is 'noisy', with the official seeking openly to criticise the illegal order, one should count it as displaying the internal point of view. The mere threat of noisy resignation might itself also count as taking the internal point of view. 'Quiet' resignation, however, which is far more normal in the civil service, is slightly more difficult to classify, since one can argue that the 'public standard' element is missing. On the other hand, the meaning of a quiet resignation as criticism will usually be very clear within government and, as in the case of Elizabeth Wilmshurst's quiet resignation as Deputy Legal Adviser to the UK Foreign Office over the legality of the Iraq War (see <http://www.iraqinquiry.org.uk/media/952I4/20Io-OI-26Transcript-Wilmshurst-S3.pdf> (accessed 5 April 2017)), that meaning will also be clear to the informed public. 
behest of a politician is important. It implies, crucially, the acceptance of an extra-constitutional source of authority.

\subsection{Coding}

Once the interviews were complete and transcribed, the responses were analysed (by eye, not with any assistance of text-analysing software) for similarities and differences. The issue of whether two responses are the same or not is clearly one of interpretation about which observers might differ. We therefore report as much as we can, within the constraint of maintaining anonymity, of what respondents said, so that readers can make their own assessments.

We initially divide our results into what we found about uniformity in official views of rules of recognition, change and adjudication before looking in more detail at uniformity of the internal point of view.

\section{The rule of recognition}

It is usually taken as axiomatic that, in the UK, the rule of recognition provides that 'what the Queen in Parliament enacts is law' (Hart, 20I 2, p. I07). It is less clear, however, what else one might include in the rule of recognition. Hart argued that the existence of the rule of recognition was demonstrated when, for example, the courts 'assert the supremacy of Acts of Parliament over other sources or suggested sources of law' (Hart, 2012, p. IOI). Hart, however, at least later, also admitted the possibility that a rule of recognition could in principle contain substantive elements, for example rules that deny the quality of law to provisions that fail a test based on values or law from multiple sources (Hart, 20I2, pp. 250-254). It has been established elsewhere that the executive has its own sources of normativity (such as minutes, informal guidance and letters) which are 'no less part of our constitutional law' than statutes (Daintith and Page, I999, p. 398; see also p. 20). Our research therefore concentrated on different, less-studied aspects of what might be contained within the rule of recognition, such as human rights standards and international law.

In some respects, a uniform view emerged. Just under half of the interviewees expressed views on whether human rights violations, whether in the form of retrospective legislation (prompted by discussion of the Poundland case ${ }^{29}$ or prisoners denied the vote or hypothetical situations such as passing Acts of Attainder, might deprive parliament of the power to make law. Twelve clearly supported unlimited parliamentary sovereignty. Even those who expressed distaste at, for example, retrospective legislation would remark that parliament was still entitled to do what it wanted or that the Human Rights Act 1998 was specifically designed to retain parliamentary sovereignty. The only respondent who expressed a view that came close to breaking uniformity was a former civil servant who declared that 'retrospective legislation is wrong and dictatorial'. Significantly, however, he prefaced that remark with the phrase 'as a citizen'. As a civil servant, he implied, his job was to uphold parliament's will. . $^{\circ}$

$29 R$ (on the application of Reilly and another) $v$. Secretary of State for Work and Pensions [2013] EWCA Civ 66 struck down the Jobseeker's Allowance (Employment, Skills and Enterprise) Regulations 20I I, SI 20I I/9I 7, at which point the government appeared to owe unpaid jobseekers' allowance to many thousands of people. It refused to pay and induced parliament retrospectively to relieve the government of these debts by means of a statute, the Jobseekers (Back to Work Schemes) Act 2013. Subsequently (and after our interviews had taken place), a declaration of incompatibility of the 20 I $_{3}$ Act was made under the Human Rights Act I998, section 4 in $R$ (on the application of Reilly (No 2) and Hewstone) $v$. Secretary of State for Work and Pensions [20I4] EWHC 2 I 82 (Admin) and later upheld by the Court of Appeal ([2016] EWCA Civ 4I3).

30 On the basis of the type of calculation referred to above, a person whose prior probability for uniformity was 0.5 and who thought that the type of questions being asked (e.g. about the Poundland case) would have a probability of being answered in a particular way of 0.5 , the posterior probability on the basis of thirteen 
The result was quite different, however, when we looked at what officials thought about the status of international law. Is it included in the rule of recognition and, if so, is domestic or international law supreme? Our interviews took place before the Ministerial Code was amended to remove the explicit mention of the need for ministers to comply with 'international law and treaty obligations' - the Code now simply refers to 'the overarching duty to comply with the law'. ${ }^{\text {I }}$ Responses to questions on the status of international law were elicited by asking respondents about a celebrated incident involving Admiral Sir Michael (later Lord) Boyce, Chief of the Defence Staff ('CDS') at the outset of the second Iraq War in 2003 (see Chilcot, 20I6, section 5, pp. 4, 9I, I23, I25-I26, I66).32 Boyce told the Iraq Inquiry (the Chilcot Inquiry) that, before committing his troops, he sought reassurance from the Attorney General as to the 'legal base' of the war.33 Boyce revealed that he was 'really quite strongly against' taking military action against Iraq. ${ }^{34}$ In requiring confirmation from the Attorney General, he noted specifically that he wanted to 'pursue a UN route', 35 thus emphasising the importance he placed on international law. After the Attorney General published his legal advice on 7 March 2003,36 Boyce was still unhappy and asked, on I I March, for an 'unambiguous blackand-white statement saying it would be legal for us to operate if we had to'.37 A parliamentary vote on the legality of the war was held on I8 March..$^{8}$

Responses were far from uniform as to whether and how parliamentary supremacy was affected by international law. The military, without exception, saw international law as a superior source of law. One former CDS said that he was 'bound by international law' because it was the source of his permission to use lethal force. Another former CDS stated that international law was what 'define[d]' the military. When asked what would happen if parliament passed a statute requiring the government to go to war, contrary to international law, yet another former CDS hesitated - the idea was clearly inconceivable to him - but then he replied: 'I don't think it's possible for parliament to do that. Parliament could pass a Bill, but there would be very serious problems if it was contrary to international law.' One former Army General was confused as to why parliament

positive trials is over 0.99. If the prior were as low as 0.2 and the question probability 0.9 , the posterior would still be 0.5 .

3I Compare Cabinet Office, Ministerial Code (October 20I5), para. I.2 with earlier versions of the Code. This amendment has prompted discussion as to whether the change was merely to save words, as the Cabinet Office has claimed, or whether that justification 'stretches credibility' and masks more insidious reasoning. See e.g. M. Elliott, 'The Ministerial Code and International Law', <http://publiclawforeveryone.com/2015/10/ 26/the-ministerial-code-and-international-law/\#more-3283> (accessed 29 March 2017).

32 The same example was used by Yong in his empirical study of government lawyers because of the 'unusual' nature of the incident and, specifically, the unusual fact that the Attorney General's legal advice was publicly available: Yong (2013, para. 6.I).

33 The Iraq Inquiry, 'Request for Witness Statement: Admiral the Lord Boyce', <http://www.iraqinquiry.org.uk/ media/96I46/20II-OI-07-Statement-Boyce.pdf> (accessed 5 April 20I7). Even revealing the fact that the Attorney General's advice has been sought, let alone its content, is typically kept confidential: see Ministerial Code, above note 3I, para. 2.I3, and Daintith and Page (I999, pp. 8, 3IO). This convention stems from the non-accountability of the Attorney General for the advice given: Windsor (2013, p. I33). The advice sought and received regarding the second Iraq War was only the fourth occasion on which the Attorney General's advice has been revealed: Yong (2013, para. 4.II).

34 The Iraq Inquiry, 'Evidence of Admiral the Lord Boyce', 27 January 20I I, <http://www.iraqinquiry.org.uk/ media/235244/20I I-OI-27-transcript-boyce-si.pdf> (accessed 5 April 2017) p. 6.

35 Ibid., at p. 9.

36 Memorandum by the Attorney General to the Prime Minister, 'Iraq: Resolution I44I', 7 March 2003, <http:// news.bbc.co.uk/I/shared/bsp/hi/pdfs/28_04_05_attorney_general.pdf> (accessed 29 March 2017).

37 'Interview: Admiral Sir Michael Boyce', The Observer, I May 2005; Attorney General, 'Disclosure Statement', 25 May 2006, para. I9, 〈http://news.bbc.co.uk/I/hi/uk_politics/50I7872.stm〉(accessed 29 March 2017).

38 HC Deb vol. 40I, cols 760-9I I, I8 March 2003; HL Deb vol. 646, cols I38-232, I8 March 2003. 
appeared to be unable to get to grips with international law, considering that he could 'get a Private to understand it'. 39

The police and local government chief executives were generally more domestically focused. One former chief constable commented that 'international law doesn't really come up in UK policing'. Another former chief constable expressed uncertainty, but eventually concluded that he thought 'parliament would have been sufficient authority'. One current local authority chief executive was similarly uncertain, but eventually concluded differently:

'I have an underlying value that democracy trumps a lot of things, but I'm not sure how far it trumps international law .... International law feels like the ultimate loyalty in some way as it is grounded in common decency.'

Responses from civil servants were not uniform. One former permanent secretary said in relation to the Boyce example:

'... it is a serious decision to go to war and so there is an assumption it will be based on UN obligations .... It is a very serious requirement to treat the Treaty obligations as if they are the law.'

Another former permanent secretary said that parliament could not 'do what it likes' when international law was involved. If parliament attempted to ignore international law in something like the Boyce example, he felt that soldiers could refuse to fight. Another former permanent secretary said that 'Parliamentary sovereignty is one of the cornerstones of our constitutional arrangement', but went on to say that 'it's harder if you've got something where the position looks against international conventions or international law'. Another former permanent secretary said that international obligations are taken seriously 'since we believe in the Treaties we sign'.

A very different view, however, was expressed by other civil servants. Two former permanent secretaries drew a distinction between international treaties 'and what we might call vague international law'. The former, because of their specificity, should always be followed, whereas the latter was less binding. Another former permanent secretary, who admitted to being 'ignorant' about international law, expressed a similar view in emphatic terms. He was scathing about the Foreign Office's reliance on international law, and especially the fact that they 'seem to have a view that international law takes precedence over our own law'. Another former permanent secretary noted that, while we 'abide by international law and [do] not overrule it, there is no such thing as international law being binding'. He noted that his 'guiding star' was the sovereignty of parliament and that he had 'always assumed that national law can override international law' even if 'you have to jump through a hell of a lot of hoops to get there'.

Perhaps most striking of all was a view expressed by a former civil servant in the course of a discussion about the relationship between international law, parliament and the government. This respondent was one of the few prepared to criticise Boyce. He did so on the basis that the most important organ for deciding what international law required was not a court, but the Cabinet. His underlying rule of recognition was equally stark: 'I think that the constitution can be changed

39 It has been suggested to us that these military figures failed to understand the chain of command and were simply ignorant of the law. The former suggestion is incorrect. They were fully aware of the relevant institutional structure, including the role of the Defence Council. They were, after all, in some cases members of these institutions. As for the latter, it is true that conventional legal advice would have told them that the UK is a 'dualist' state in which international law has no domestic effect unless incorporated by domestic law, but, unlike some lawyers, the military understands only too well that UK domestic law cannot alter international law and that international law is developing in the direction of individual responsibility for people such as senior military officers. 
by the Cabinet.' That view might be extreme and at odds with those of other officials. It is nevertheless consistent with the executive's long-standing practice of adopting its own sources of normativity..$^{\circ}$ It amounts, perhaps, to an executive branch riposte to the lawyers' theory that the constitution is a creature of the common law (see e.g. Allan, 2013).

\section{Rules of change}

Rules of change govern how laws are modified, added to or removed (Hart, 20I2, pp. 95-96). The standard method of such change is 'legislative enactment and repeal' (Hart, 2012, p. 95). Views were sought as to whether votes or debates in the House of Commons alone sufficed to change the law. ${ }^{\text {I }}$ Relevant remarks sometimes flowed from the discussion of the Boyce incident. Other respondents were asked about Theresa May's motion in the House of Commons in June 201 $2^{42}$ :

'That this House supports the Government in recognising that the right to respect for family or private life in Article 8 of the European Convention on Human Rights is a qualified right and agrees that the conditions for migrants to enter or remain in the UK on the basis of their family or private life should be those contained in the Immigration Rules.'43

May intended that the motion should influence judicial interpretation of Article $8^{44}$ and the motion was unanimously passed. It did not, however, make a big impact on the courts. For example, the Immigration and Asylum Chamber of the Upper Tribunal refused to be bound by what it considered a 'weak form of Parliamentary scrutiny'. 45

Many respondents agreed that, unlike legislation, parliamentary motions did not change the law. One former permanent secretary dismissed May's view that her motion on Article 8 could alter the law as 'wishful thinking'. A current civil servant agreed, but added that he doubted whether May really expected to change the law. He surmised that she aimed merely to 'send a message' and to give 'political cover' rather than to influence the judiciary. Other than that, he thought, the debate had 'achieved nothing'. He added that civil servants had blocked 'quite a few' similar attempts by ministers. Another current civil servant said it would make him 'unhappy' if a minister tried to change the law in his area by means of a motion rather than by legislation. Another former permanent secretary expressed his opposition even more strongly, arguing that the current trend for 'less extensive and consultative means' of changing the law was 'pathetic'. A former CDS was equally hostile, stating that any belief that a debate or vote in the Commons could change the law was 'arrant nonsense'. A former chief constable said simply that a parliamentary resolution did 'not chang[e] the law'. A local government figure was similarly succinct in rejecting votes or debates as sources of legal change because 'that's not how the constitution works'. Two former permanent secretaries claimed that ministers employ May's tactic 'at their peril' because, in their

40 See above, p. I2.

4I Some time after our interviews, the Supreme Court held that 'A resolution of the House of Commons is an important political act .... But .... A resolution of the House of Commons is not legislation': R (Miller and Dos Santos) v. Secretary of State for Exiting the European Union [20I7] UKSC 5, at [123].

42 Eighteen respondents were asked about this example, predominantly but not exclusively civil servants.

43 HC Deb vol. 546, cols 760-823, I9 June 2012.

44 T. May, “It Is Not for Judges to Be Legislators”: Home Secretary's Public Attack on Rebel Judges', Mail on Sunday, I7 February 20I3. For the political context, see Laws (20I6) and Featherstone (20I6). May's political problem was that she was blocked by her coalition partners from introducing primary legislation. 
view, public opinion was generally more favourable to the courts than to politicians, and that a conflict with the judiciary would not 'end well for government'.

Complete uniformity, however, was not achieved. Another current permanent secretary remarked that, although votes and debates did not have the same status as legislation, 'there is a point in trying' if they might 'sway' a court. A former CDS expressed the same view. A former Cabinet secretary thought that 'judges should take [votes and debates] into account, but they should not be bound by [them]'.46 Those views do not challenge the current rules of change directly, but they do amount to trying to work around them. One former permanent secretary, however, went much further, asserting straightforwardly that the Commons motion on Article 8 should count as having changed the law: 'If the resolution has been voted on and approved by the House and it is clear that they are serious about it then I think judges should follow it.'

Perhaps the most extreme example of the view that a Commons resolution might change the law came in a discussion of what would happen if the courts had ruled unlawful the invasion of Iraq despite a Commons resolution in favour of it. A current civil servant queried the legitimacy of any such judicial decision:

'If the judiciary were willing to entertain a case on going to war, the government would probably argue that the House of Commons debate had a higher status, but that would be as part of a wider discussion on the court having no business in such decisions anyway.'

This was not merely the conventional point that the courts should defer to the judgment of the political branches in matters of national security. 47 Rather, it was being asserted that, if the courts fail to defer to the political branches' primacy, the courts' view of the rules of change could be ignored and the Commons' view should prevail.

\section{Rules of adjudication}

Rules of adjudication provide a mechanism for determining what the rules require in specific cases when disagreement or uncertainty appears (Hart, 20I2, pp. 96-98). The function is typically performed by judges and courts (Hart, 20I2, p. 97). That, indeed, is the view of adjudication we found among local government chief executives. They regularly mentioned judicial review as one of the main adjudicatory options open to the authority when faced with adverse centralgovernment decisions, although one chief executive bemoaned the fact that it was not a popular choice with the public. Another chief executive, when asked how he would find out the legal position on an issue, immediately responded that it would be through judicial review, especially '[i]f something had a real adverse effect on [this area]'. Another current chief executive noted that, where the law is unclear, her tactic is usually to 'take a reasonable position and ultimately leave it to the courts'.

We also found frequent mention of subsidiary or additional methods of determining what the law requires, including reference to counsel and consultation among colleagues. One former permanent secretary noted that he would engage counsel (rather than using his own internal lawyers) on 'sensitive' issues, but that external advice was not restricted to such issues, and was therefore quite common. Daintith and Page noted in the I9gos that the Attorney General had

46 In this and in what follows in this section, references by officials to 'judges' or 'the judiciary' are all, in context, references to UK domestic judges sitting in domestic courts and not to the judges of the ECtHR.

47 See e.g. A v. Secretary of State for the Home Department [2004] UKHL 56, at [I07] and [I I6], per Lord Hope of Craighead, and at [29], per Lord Bingham of Cornhill, although note the limits of deference mentioned by Lord Bingham at [44] and also note Lord Hoffmann's judgment, which famously proceeds on a different basis. 
issued guidance to curtail the contracting out of legal services (Daintith and Page, I999, pp. 2 I3-2 I4), but the situation seems to have changed, possibly because of the continuing growth of judicial review (Yong, 2013, paras I.I-I.3; see also Windsor, 2013, for other reasons this might have happened).

Consultation among colleagues was also prevalent in all sectors, and particularly within the civil service and local government (Yong, 2013, para. 4.6 also noted that informal advice from government lawyers was 'very common'). One former permanent secretary was quite clear that '[w]hat you do when you don't know what to do is sit down and talk to each other'. A current permanent secretary agreed, noting that his first point of contact any time he has a question or a difficulty are his predecessors. A former Cabinet secretary remarked that people simply talk to one another to ascertain the law and that it was 'an utterly British way of doing it'.48 Similar patterns of using professional and personal networks appeared in the military and local government respondents.

None of this is perhaps particularly different from what happens outside government. When we look more closely at central government, however, we find something else: a rival to the courts in making adjudications - a rival whose authority goes beyond that of references to counsel or informal consultations with colleagues. That rival is the Attorney General. For several civil servants and for some of the military, whatever the Attorney General says is law is law. As Daintith and Page noted, for many inside Whitehall, the description of the Attorney General as the government's chief legal adviser is misleading. As they found, his role is 'broader' than the word 'adviser' might suggest, having a 'special quality and status' (Daintith and Page, I999, p. 297). A succession of central government figures told us that the Attorney determines what the law is. ${ }^{49}$ For example, one former permanent secretary noted that, when Admiral Boyce wanted to go to the Attorney General, 'The Attorney General was being asked "what is the law", not "[what is] the likelihood of being sued"'. Another said: 'The PM and the Foreign Secretary must seek the opinion of and obey the law officers.' Yet another said, referring to the legality of the war in Iraq:

'What if the Attorney General had said it was not legal? That would have been it. If it's not lawful, you can't instruct an official to do it. You can't instruct me, because if you do, I will not do it.'

A further perhaps paradoxical indication of the binding nature of the Attorney's determinations was that respondents reported occasions on which the prime minister knew he would not like the Attorney General's view and so 'he made sure not to ask him'. Yong noticed a similar process, remarking that the delay in seeking the Attorney General's advice on the second Iraq War was 'possibly because the Prime Minister feared it would not support his chosen course of action' (Yong, 2013, para. 6.24). Why take active steps to avoid taking the Attorney's advice, especially since evasion can itself cause problems, $5^{\circ}$ unless its effects once given are 'final and determinative' (Yong, 20I3, para. 4.4)?5I

48 See also Peter Hennessey's interviews of Cabinet Secretaries, above note I9.

49 In this respect, the law officers are carrying out a core executive function, namely acting as 'final arbiters of conflicts between different elements of the government machine': see Rhodes (2007, p. I247). But the prime minister's ability to avoid asking for a decision is possibly an example of the kind of manoeuvre to be found in 'court politics' - see Bevir and Rhodes (20I6).

50 The Ministerial Code sets out a duty to consult the law officers 'in good time before the Government is committed to critical decisions involving legal considerations' (Cabinet Office, Ministerial Code (October 2015), para. 2.I0). Daintith and Page (I999) note the possible intra-governmental ... [and] public embarrassment' of failing to seek and obtain the Attorney General's advice (p. 302).

5I Yong also notes that other subordinate governmental lawyers' advice may be viewed as determinative in certain circumstances: Yong (20I3, para. 4.22). Cf. Daintith and Page (I999, p. 3I2), where the hypothetical scenario is presented of an Attorney General resigning when his advice is not taken, and Yong (2013, paras 6.IO-6.I3), where it is noted that the advice of the Attorney General (and other legal advisers) was not 
There is no uniformity on this point, however. About half of our central government respondents made comments that can be interpreted as attributing an adjudicatory role to the Attorney General, but the other half did not, most of them indicating support for a mere 'advisory' role.

Another interesting aspect of the Attorney General's role is that, although central government officials did not deny that the courts were entitled to interpret the law, those interpretations were not universally and invariably treated as automatically applicable within government without further confirmation from the Attorney General. As has been observed elsewhere, the Attorney General functions as 'a buffer' between politicians and lawyers (Yong, 2013, para. 4.8). The degree of that buffering can, however, go too far for the courts. In 20I5, in $R$ (Evans) v. Attorney General, ${ }^{2}$ Lord Neuberger found it necessary to repeat Lord Templeman's condemnation in $M v$. Home Office $e^{33}$ of 'the proposition that the executive obey the law as a matter of grace and not as a matter of necessity'. We heard what appeared be an echo of that proposition when a former permanent secretary, on being asked about the effect of a European Court of Human Rights decision on prisoner voting, commented that, rather than complying, he would seek the Attorney General's advice. He suspected that '[t]he Attorney General will say "I'm afraid you have got to comply", but he would be unwilling to comply immediately without seeking such validation. Admittedly, that example arose in the context of a decision by an international court, not the domestic courts involved in Evans and $M$, and we did hear a rival story that, although officials often very much resent judicial decisions, they nevertheless comply without further ado,54 but it at least suggests an area for further investigation. The executive preference to keep the courts 'out of its "own affairs"' is well known, 55 but the view condemned by Lord Neuberger and Lord Templeman goes further. It treats the courts as an alien force and would help to justify the executive setting up its own rival 'insider' process of adjudication..$^{56}$

\section{The internal point of view}

The test devised for whether officials maintained an internal point of view was whether there were circumstances in which, on political instruction, they would refuse to comply with what they knew to be the law. ${ }^{57}$ Evidence of officials adhering to the internal point of view was not lacking. Many civil

followed in relation to the Suez Crisis. The then Attorney General (Manningham-Buller) threatened resignation, but did not ultimately resign.

52 [20I5] UKSC 2I, at [53].

53 [I994] I AC 377, 395. It should be mentioned that the Attorney General of the day was directly involved in the management of this case (personal communication to the authors from one the Home Office's counsel).

54 One permanent secretary raised deportation cases (particularly the case of Abu Hamza al-Masri), observing that such cases 'show ministers accepting that they're bound ... by the court's interpretation, otherwise they would just put people on planes. It causes immense frustration and anger but they don't ignore the courts'. See also Daintith and Page (I999, pp. 326-330) on the executive’s 'subservience to the judiciary'.

55 Daintith and Page (I 999, p. 393). Page (200I, pp. 72-73) found that civil servants behaved 'as if the judge were there by their side', though not in a friendly way.

56 It has been suggested to us that the Attorney's role in providing adjudication on the law within government arises simply as a matter of convenience because the courts will only clarify the law where there is an active dispute between a citizen and the state. The problem with this argument is that, because of the generous rules on standing operated by the English courts, it is very easy to generate a public law case on which the courts will adjudicate. The main practical advantage of adjudication by the Attorney over adjudication by the courts is rather secrecy, which is itself an aspect of separation between the executive and the courts.

57 See above for the justification of this as a test for the internal point of view. Civil servants were specifically asked what use (if any) they had made of the written direction procedure, under which civil servants not content with a ministerial instruction on grounds of regularity, propriety or value for money ask for the 
servants indicated that, in a situation in which they were being asked to do something unlawful, they would not comply. The situation was different from one in which they had doubts about a policy's wisdom or value for money, in which they might go along with their minister's wishes or, in extremis, resign. In Page's research, only two civil servants reported an objection to a particular policy they had to implement. They nevertheless thought it would be 'unprofessional' not to publicly defend the policy as 'a very good idea' (Page, 200I, p. II4). But, for several officials, legality was a different matter. One former permanent secretary told us that 'there is the expectation that the Permanent Secretary sometimes draws lines and says he cannot do that'. He remarked, using the Pergau Dam case as an example, ${ }^{8}$ that he did not think he 'could have been directed to do something illegal or unlawful'.

Another former permanent secretary described as 'nonsense' the suggestion that civil servants should view disagreement on policy and legality in the same way and either comply or resign. He explained that 'if it's not lawful, you can't instruct an official to do it'. Two former permanent secretaries asserted that, specifically 'in matters of war and peace', resistance to illegality was a viable option and that officials did not face the forced choice of complying or resigning.

The view of the military was similar. One officer drew a line between issues of 'dubious legality' and proposals he simply disagreed with. With regard to the former, he felt that he could refuse to carry out the order. With regard to the latter, however, he felt that the military had to 'either salute and get on with it or, if you wouldn't be able to live with yourself, you resign'. He concluded that 'The military does not just do whatever it wants. And we don't just do everything we're told'. A former General agreed, saying 'as a General, I shouldn't obey illegal orders, so I have every reason to question it. That was taught to me from the beginning'.

Local government officials were clearer still that they would refuse to obey unlawful orders. One current chief executive said:

'[Sometimes you have to] stand up and be counted where you can't be wilfully blind. Sometimes you think if no-one else is complaining then it is fine, but there is a tipping point where you think "I can't do this anymore".'

instruction to be put in writing (see Harris (2013)). The responses we received might form the basis of further work on the topic itself. Experience varied considerably as to the extent of the use of that procedure during civil servants' careers. One former permanent secretary said he had used the procedure twice, and noted that its use 'needn't be controversial'. Another former permanent secretary said that the threat of using the procedure was used considerably more than the procedure itself. Yet another former permanent secretary, however, described the written direction procedure as the 'nuclear option' and argued that a permanent secretary 'would be an idiot to constantly threaten written direction'. He did note, however, that the procedure was useful in adding 'formality' to the relationship between permanent secretary and minister, and that 'big politicians' did not mind its use because 'it shows the buck stops with them'. Another former permanent secretary noted that new ministers were more likely to be shocked by the use of the procedure, and that one such minister had accused the permanent secretary of 'threatening' him. One of us has personally been in a situation in which an accounting officer announced an intention to ask for a written direction if a certain course of action were taken and can report that it did indeed feel like being threatened or coerced.

58 A grant of over $£ 200$ million to build a hydroelectric dam in Malaysia was held unlawful in $R v$. Secretary of State for Foreign and Commonwealth Affairs, ex parte World Development Movement Ltd [I995] I WLR 386. The Overseas Development and Co-operation Act I980, section I(I) gave the Secretary of State power 'to furnish any person or body with assistance, whether financial, technical or of any other nature' for promoting 'the development or maintaining the economy of a country or territory outside the United Kingdom, or the welfare of its people'. The grant was ultra vires because it was not made for any of the stated purposes. 
The legal protection offered to the Head of Paid Service in local authorities gave them some basis for that position, 59 but they recognised that the practical political consequences of defiance might well be a conflict they would in the end lose. ${ }^{60}$ Chief executives typically noted that 'if the relationship between the Leader [of the council] and the chief executive goes wrong, it's the chief executive who has to leave, not the Leader'. ${ }^{61}$ Nevertheless, refusal was usually seen as correct behaviour. ${ }^{62}$ Another current chief executive continued:

'I have been asked a lot of times by politicians to do things and I have refused .... If you do something just because people put pressure on you, you have no integrity. If I fall out with my political executive, I am out of it. But I would rather not have a job than do the wrong thing. What am I worth if my integrity is not intact?'

She continued to say that she would not resign under such circumstances: 'Standing up, not resigning, is the right thing to do.'

Crucially, however, some civil servants indicated that they would follow a ministerial order even if they knew that order to be unlawful. One former permanent secretary said he had asked for a ministerial written direction where he was ordered to do something that had 'no legal base'. Despite being sure that the action would be struck down if judicially reviewed, after receiving a written instruction, he was happy to go ahead. It was enough that the minister went into it with his eyes open'. Another former permanent secretary agreed that a written direction was the correct 'mechanism' where 'government is intent on policy which is illegal under domestic law'. Having received a written instruction to carry out an illegal order, he was quite clear that he would have to 'either carry it out or resign'. Some police officers also thought that they had to follow orders. In relation to the Boyce example, one former chief constable noted that, regardless of the legality of the war, if Boyce had refused to go to war, it would have amounted 'mutiny'. ${ }^{63}$

Such views might be surprising, but they are consistent with the response we recorded to the 'Poundland' case that some civil servants felt comfortable with refusing to follow a court judgment if their minister's view, having the support of the House of Commons, was that the court should be resisted. More generally, a former permanent secretary said that it was 'not uncommon that legal advice says the chances of a court striking [the decision] down are high' yet 'ministerial decisions might still go ahead', apparently without protest from civil servants. ${ }^{64}$

59 See $R$ (Lock) v. Leicester City Council [201 2] EWHC 2058 (Admin), at [29]-[37] for a summary.

60 Note that the legal protection is not particularly strong. See e.g. $R$ (Lock) v. Leicester City Council [2OI 2] EWHC 2058 (Admin) itself, where the chief executive's attempts to use the law to stay in post completely failed.

6I Readers should note that one of the researchers had personally been a council leader with direct personal experience of the relationship between the leader and the chief executive of a local authority and that respondents might have been influenced by that fact. The statement in the text does, however, also reflect that researcher's own experience of the legal and political realities of the relationship. Admittedly, sometimes both the leader and the chief executive end up leaving, but that hardly counts as a win for the chief executive. See e.g. 〈http://www.telegraph.co.uk/news/uknews/I509360/Liverpool-regeneration-projectpair-quit.html> (accessed 29 March 2017).

62 This view was not universal, however. One current chief executive argued: 'If I am told to do something and I really don't like it, I'd have to leave.' Another current chief executive's views were somewhere in between: 'My instincts are that if the democratic process decides that something should happen, my role is to make it happen unless I think there is some sort of problem in making it happen.'

63 That view was not universal, however. Two other former chief constables gave examples of incidents in which they had refused to follow political instructions of doubtful legality.

64 In Yong's empirical research, no government lawyers spoke of ministers suggesting deliberately illegal courses of action, but several interviewees reported that the lawyers often had to point out that a particular course of action was contrary to European law: Yong (20I3, para. 5.I2). His research does not explore in detail whether 


\section{Is there a uniform internal point of view?}

What can we say, bringing the evidence together, about whether UK officials have a uniform internal point view of the UK's rules of recognition, change and adjudication?

As we laid out above, that question has two parts: are views uniform and are they uniformly internal? In some respects, views are uniform. We found very little evidence, for example, that UK officials are currently tempted by any substantive restrictions on parliamentary supremacy. Whatever the views of certain judges, and whatever the hopes of certain theorists, we found only the beginnings of uncertainty and hesitation about the effect of the human rights thinking on what counts as law. Both on retrospectivity and on human rights, officials turned to a straightforwardly hard positivist view of the supremacy of parliament in domestic law.

In other respects, however, even in our small sample (which itself might be biased towards uniformity), official views were very far from uniform. The most striking is the status of international law. The military and some officials associated with defence and foreign policy tended to say that parliament could not alter or relieve the obligations of international law. They felt bound directly by international law regardless of what parliament or the government thinks. Other officials distinguished between treaty obligations, which were binding, and 'vague' international law, which was not. Others still distinguished between international law about war and peace and other types of international law. In sharp contrast, others, both in central government and in local government, believed international law to be entirely subordinate to domestic legislation, or even to the democratic will of the House of Commons as expressed in a resolution. ${ }^{65}$

Lack of uniformity also appeared about adjudication. Outside central government, the conventional view holds sway, namely that the courts provide the only authoritative interpretations of the law, although there might be other more informal methods that work better from day to day. But, inside central government, a different theory has supporters, according to which the Attorney General gives authoritative interpretations of the law. In an extreme variation on that theory, the Cabinet itself, on the advice of the Attorney, ${ }^{66}$ is taken to be the highest interpreter of the law.

Moreover, the conventional view of the rules of change - that parliament can change the law only by means of acts of parliament or authorised secondary legislation - is fraying at the edges, with support being found for the view that, whatever the House of Commons votes for, even if merely in the form of a resolution, should be capable of changing the law. Many still take the older view but strict uniformity does not exist.

or how frequently legal advice is not followed, except to note that it may not always be followed when it regards the prudence, rather than the legality, of a policy (para. 5.25).

65 It has been suggested to us that we are basing our view that uniformity is lacking on the issue of the relationship between international and domestic law on the views of the final interviewee mentioned above in Section V. That is not so. It is based on the lack of uniformity across all officials, with that final official acting as an outrider. It was also suggested to us that the officials we interviewed might not have had any contact with issues affected by the relationship between international law and domestic law. It is difficult to refute that accusation directly without compromising anonymity but, in any case, given that the relationship between international and domestic law goes to the heart of the effects (in different ways) of both EU and ECHR law on domestic law, we would contend that there is no such thing as a government department whose work is unaffected by that relationship.

66 Although he attends Cabinet, by convention, the Attorney General is not a member of Cabinet. On the 'considerable controversy' on the matter, and the different rule from time to time between I9I 2 and I928, see Daintith and Page (I999, pp. 235-236). That liminal status reflects a deeper ambiguity about the role: whether they are 'detached professionals' or 'full ministerial participants in government' (p. 234). 
Lack of uniformity is perhaps unsurprising given that, as Daintith and Page observed, the autonomy of individual government departments is 'central' to our constitution (Daintith and Page, I999, p. 58). That autonomy includes differing departmental attitudes as to when and how legal advice is sought (Daintith and Page, I999, p. 333). Furthermore, Daintith and Page found that the Government Legal Service at that point in time lacked 'co-ordination and coherence', so that the legal advice given was not centralised (Daintith and Page, I999, p. 322; see also Yong, 2013, Chapter 2, although it is important to note his comments on attempts to ensure 'some consistency and coherence in legal advice across Whitehall' by way of informal groups (executive summary para. 7, Chapter 2 and para. 4.I4) and his observation that the finality of the Attorney General's advice may provide some consistency (para. 4.4)). But, for lack of uniformity to break out on a question about which lawyers, as far as we know, would not themselves disagree is surprising.

Moving on to the internal point of view, it is very striking that some senior civil servants regard their duty to support their minister as superior to any duty to comply with the law. That view seems more common among civil servants than among local government officials, who start from a different legal base, though not necessarily from a different practical one, and the police, though it is not entirely absent even there. It is difficult to see how these officials are taking the internal point of view. One cannot even say they are giving a false impression of accepting the rules. All they might argue is that their defiance is not public and so not necessarily a direct threat to stability.

\section{Implications}

On their face, these results, albeit derived from a small study, seem to suggest that Hart's account is at least seriously incomplete. If we accept that the UK does have a legal system, we seem to need more than Hart's account of what officials believe to explain its persistence. We concede, however, that an argument from tolerance might be made in each of the examples we have identified. The argument would be that the degree of official disagreement we have found about the status of international law, the role of the Attorney General, the status of Commons resolutions and on whether civil servants are prepared to break the law does not add up to a threat to the operativeness of the legal system. These examples, the tolerance argument would claim, are minor perturbations that pose no threat to the system as a whole. For practical purposes, Hart's theory would remain intact.

One objection to taking a complacent view is the high salience of the issues associated with the areas of lack of uniformity. In particular, the relationship between international law and domestic law lies at the heart of a series of immensely important issues in early twenty-first-century British politics: the relationship between the UK and the EU, the future of human rights legislation and lessons of the second Iraq War. The options a state faces on that relationship are no more difficult to grasp than any other issue in elementary constitutional law, but disagreement about them potentially affects not only issues of political strategy, but also everyday decisions about such matters as prisoner voting rights and economic policy.

Another objection to the complacent view is that, although each point taken individually might cause only minor ripples in the operativeness of the UK's legal system, if circumstances arose in which they came to be combined, the situation might be far more serious. The Boyce situation itself, if it had gone down a different route, is a case in point - the clash about the status of international law, combined with rulings from the Attorney General possibly at odds with rulings from the courts and claims of high authority made for resolutions of the House of Commons might easily have produced a situation in which UK armed forces were receiving contradictory instructions about going to war and the populace were faced with a military denying the principle of civilian control over the armed forces. 
A further point, relating specifically to the results on the internal point of view, is that the situation might deteriorate rapidly if the population became more aware of the views of some civil servants and police officers that they should sometimes defy the law. The lack of an internal point of view would threaten not only their personal credibility, but also the legitimacy of the whole system.

\section{Questions raised for further research}

The results here are only suggestive. A full-scale study, qualitative and quantitative, difficult as that might be to organise, might show that the dissident views we found are held by very small minorities and so would not in reality pose much of a threat to the operativeness of the legal system. But what if they are not held only by insignificantly small minorities? What would be the implications if our findings were replicated at scale?

One set of implications, and a justification by itself for more research on these questions, would concern the compatibility of different directions of change in the secondary rules. A move towards incorporating international law into the rule of recognition implies a restriction on the legal powers of domestic majorities, but a move towards allowing simple resolutions of the Commons to change the law implies an expansion of the powers of domestic majorities. Would such changes be contradictory or complementary? They might seem politically to be complementary, but legally they look contradictory and a possible source of future conflict and instability. Moreover, a movement in favour of majoritarianism in the rules of change justified by appeals to democracy might have a knock-on effect on the rule of recognition, for, if a government can change the law by a resolution of the Commons, what is the point of the House of Lords?

Another set of implications justifying further work is more social scientific. We have found some evidence of the existence of a uniform internal point of view, but also evidence of its absence. If larger studies were to confirm our findings, can we say that Hart was wrong? The simple answer to that question seems to be 'yes'. Hart claimed a wider uniformity than seems to exist. But if, following Galligan's view, we think of Hart's account as an ideal type, the immediate question is whether Hart's view is so wrong that we should discard it completely. We arguably found sufficient uniformity that one might perhaps regard throwing Hart's ideal type out entirely as precipitate. On the Weberian interpretation of Hart, we would need to ask whether we could identify other ideal types, in the sense of analytical constructs built out of one-sided accentuations of social practices, capable of explaining the part of social reality left unexplained by Hart.

One possibility is that we might need an ideal type built around an official who acts according to political imperatives rather than legal rules. Indeed, some of our officials - those who stressed settling constitutional questions by negotiation and mutual adjustment - might themselves serve as the basis of such an ideal type. ${ }^{67}$ From a Hartian point of view, the ideal type of the political official represents a form of lawlessness. Many of the civil servants we interviewed were indeed candid about their, and their ministers', distaste for the courts. ${ }^{68}$ But the political official type is more subtle than merely someone who finds the judiciary irksome. It involves 'balance' and accommodation between law and politics. For example, a former Cabinet secretary revealed that he had organised private meetings between senior colleagues and the judiciary with the objective of assisting mutual understanding. His summary of the situation was: 'There has always been tension. The judges

67 See e.g. as a source for such an ideal type Peter Hennessey’s interviews with Cabinet Secretaries, above note I 9.

68 One former permanent secretary said it 'drives ministers mad' when judges express a view of the law contrary to that of the government. See also above note 54 . 
quite rightly assert their independence and the politicians their sovereignty. But the relationships were not always bad behind the scenes.' 69

The political official ideal type, however, is not the only possible further explanation that might account for the part of social reality left unexplained by Hart. The evidence suggests that officials might not simply reject the rules of recognition, change and adjudication conventionally accepted by the courts and by textbook writers. They might also have their own different rules or at least their own debates about what the rules should be - for example, whether international law is superior to domestic law, whether Commons resolutions should have legal effect and in case of dispute or uncertainty whether the Attorney General, or even, according to a particularly extreme view, the Cabinet, decides what the law is. That suggests in turn a different explanation based around not a rejection of strict legality or of government through rules, but instead a plurality of such rules. It would be as if a legal system exists formed around and operated by the courts, but another legal system exists based in government and centring on the Attorney General. The two systems would have similar views on many basic matters but they might not entirely coincide and might have different degrees of internal coherence. The degree of conflict between them would have to be managed by their leading participants, in particular the law officers on one side and the senior judiciary on the other. It would still be a matter of 'balance' and adjustment, but between different systems of rules rather between law and politics.

The extent to which a plurality of systems of rules exists within the British state is at this stage more a topic for future research than a firm conclusion. One might, however, point to a parallel in the relationship between the courts and parliament in the UK. One can see parliament as attempting through Article 9 of the Bill of Rights to assert a zone of lawlessness. That seems to be the judges' view of parliamentary privilege. ${ }^{70}$ A different view, however, is that parliament, or at least a group of people within parliament, is asserting that it has its own separate legal system - a lex parliamentaria in the literal sense - with its own rules of recognition, change and adjudication. ${ }^{71}$

Another direction for future research would be to ask whether the situation in the UK is unique. The idea that state officials might not always be inclined to follow the law might be shocking to those who have built their constitutional theories exclusively on the idea the Rechtsstaat, but that by itself does not rule out the possibility. Results similar to those of the British case are far from impossible elsewhere, especially in countries (in Scandinavia, for example) where the concept of judicial supremacy is not universally accepted. Even where that principle is, more or less, accepted, for example in the US, difficulties surrounding locus standi and doctrines limiting justiciability, such as the political question doctrine, leave much scope for officials in the other branches of government to conduct themselves in a Hartian or in a non-Hartian way..$^{72}$

69 He did, however, add: '[I]t is much more difficult now with the Human Rights Act... There is always a tension and there should be; that is healthy. But the degree of heat that builds up behind it should be watched.' The growth in judicial review has been another source of antagonism: Daintith and Page (I999, p. 339).

70 See e.g. $R v$. Chaytor [20I0] UKSC 52.

7 I Roughly: what the House votes for by majority is law, that the House can change any previous rule by majority and that (in the Commons) the Speaker adjudicates on disputes about what the law is.

72 We are grateful to one of the anonymous reviewers for this point. Another suggestion is that it might make a difference that the UK constitution is 'unwritten' (even though much of it is 'written', albeit not codified), the argument being that it would be easier for officials to come to the same interpretation of fundamental rules if the rules are written down. That is possible, but written constitutions inevitably fail to anticipate all the issues that might arise under them, and that sometimes includes even the most fundamental issues. The US Constitution, for example, fails to say whether the courts can strike down statutes (Marbury v. Madison 5 US I37 (I803)) and the German Basic Law contains no express rule about whether German constitutional law prevails over EU law or EU law over German constitutional law (BVerfGE 37, 27; BVerfGE 73, 339). In any case, as Hart himself pointed out, 'a penumbra of uncertainty must surround all legal rules' (Hart (I958, p. 607)) and so writing them down does not necessarily make them clearer. 
In the end, it might turn out that, to capture the whole range of what is happening, and to explain both long-term stability and change, we will need both the political official ideal type and the idea of competing systems of rules, and that both will supplement rather than replace Hart's ideal type of officials who share the same views and criticise their peers who fail to conform. Social reality does not need to be simple.

\section{References}

ALLAN, T.R.S. (2013) The Sovereignty of Law: Freedom, Constitution and Common Law. Oxford: Oxford University Press.

BEVIR, Mark and RHODES, R.A.W. (2006) Governance Stories. Abingdon: Routledge.

Bevir, Mark and RHODEs, R.A.W. (2010) The State as Cultural Practice. Oxford: Oxford University Press. BEVIR, Mark and RHODEs, R.A.W. (20I6) 'The 3 Rs in Rethinking Governance: Ruling, Rationalities and

Resistance' in Mark Bevir and R.A.W. Rhodes (eds) Rethinking Governance. Abingdon: Routledge. CHILCOT, John (2016) The Report of the Iraq Inquiry. London: TSO.

DaInTITH, Terence and Page, Alan (I999) The Executive in the Constitution. Oxford: Oxford University Press.

Davis, Kenneth Culp (I97 I) Discretionary Justice: A Preliminary Inquiry. Urbana: University of Illinois Press.

EndicotT, Timothy (2013) 'The Generality of Law' in Luís Duarte d'Almeida, James Edwards and

Andrea Dolcetti (eds) Reading H.L.A. Hart's The Concept of Law. Oxford: Hart Publishing. FEATHERSTONE, Lynne (2016) Equal Ever After. London: Biteback.

Galligan, Denis (2015) 'Concepts the Currency of Social Understanding of Law: A Review Essay on the

Later Work of William Twining', Oxford Journal of Legal Studies 35: I-29.

GARDNER, John (20I2) Law as a Leap of Faith: Essays on Law in General. Oxford: Oxford University Press. GARFINKEL, Harold (1967) Studies in Ethnomethodology. Englewood Cliffs NJ: Prentice-Hall.

Goldsworthy, Jeffrey (200I) The Sovereignty of Parliament: History and Philosophy. Oxford: Oxford

University Press.

HARRIS, Josh (2013) Following the Pound: The Accounting Officer in Central Government. London: Institute

for Government.

HART, H.L.A. (1958) 'Positivism and the Separation of Law and Morals', Harvard Law Review 7I:

593-629.

HART, H.L.A. (1983) Essays in Jurisprudence and Philosophy. Oxford: Oxford University Press.

HART, H.L.A. (1994) The Concept of Law, 2nd edn. Oxford: Clarendon.

HART, H.L.A. (2012) The Concept of Law, 3rd edn. Oxford: Oxford University Press.

HART, H.L.A. and sugarman, David (2005) 'Hart Interviewed: H.L.A. Hart in Conversation with David

Sugarman', Journal of Law and Society 32: 267-293.

howarth, David (1992) 'Making Sense out of Nonsense' in Hyman Gross and Ross Harrison (eds)

Jurisprudence: Cambridge Essays. Oxford, Clarendon Press.

JACKMAN, Simon (2009) Bayesian Analysis for the Social Sciences. Chichester: John Wiley.

KRAmer, Matthew (2013) 'In Defense of Hart' in Wil Waluchow and Stefan Sciaraffa (eds) Philosophical

Foundations of the Nature of Law. Oxford: Oxford University Press.

LACEY, Nicola (2006) 'Analytical Jurisprudence Versus Descriptive Sociology Revisited', Texas Law

Review 84: 945-982.

LAws, David (2016) Coalition. London: Biteback.

LIPSKY, Michael (I980) Street-level Bureaucracy. New York: Russell Sage Foundation.

LLeWellyn, Karl and hoEbel, E. Adamson (I94I) The Cheyenne Way. Norman, OK: University of

Oklahoma Press.

maccormick, Neil (2008) H.L.A. Hart, 2nd edn. Stanford: Stanford University Press. 
MASHAw, Jerry (1983) Bureaucratic Justice: Managing Social Security Disability Claims. New Haven: Yale UP.

MAYNARD-MOODY, Steven and PORTILLO, Shannon (20I0) 'Street Level Bureaucracy Theory' in

Robert Durant (ed.) The Oxford Handbook of American Bureaucracy. Oxford: Oxford University Press. PAGE, Edward (200I) Governing by Numbers. Oxford: Hart.

RAz, Joseph (1979) Authority of Law: Essays on Law and Morality. Oxford: Clarendon Press.

RHODES, R.A.W. (I997) Understanding Governance. Buckingham: Open University Press.

RHODEs, R.A.W. (2007) 'Understanding Governance: Ten Years On', Organization Studies 28: I 243-I 264. SCHAUER, Frederick (2006) '(Re)taking Hart', Harvard Law Review I I g: 852-883.

SEARLE, John (1995) The Construction of Social Reality. London: Allen Lane.

tamanaha, Brian (200I) A General Jurisprudence of Law and Society. Oxford: Oxford University Press. Weber, Max (I949) 'Objectivity in Social Science and Social Policy' in Edward A. Shils and Henry A. Finch (eds and trans.) The Methodology of the Social Sciences. New York: Free Press.

WEBER, Max (1978) Economy and Society, trans. Guenther Roth and Claus Wittich. Berkeley: University of California Press.

WINDsoR, Matthew (2013) 'Government Legal Advisers through the Ethics Looking Glass' in David Feldman (ed.) Law in Politics, Politics in Law. Oxford: Hart.

Yong, Ben (2013) Risk Management: Government Lawyers and the Provision of Legal Advice within Whitehall. London: The Constitution Society/The Constitution Unit Report. 